\title{
Bilgi Teknolojileri ve Hastane Bilgi Sistemleri Kullanımı: Sağlık Çalışanları Üzerine Bir Araştırma
}

\author{
The Use of Information Technology and Hospital Information \\ Systems: A Study on Health Employees
}

\author{
Oğuz IŞIK* ve Mahmut AKBOLAT**
}

\begin{abstract}
Öz
Bu çalışmanın amacı, sağlık çalışanlarının bilgi teknolojileri ve hastane bilgi sistemlerini kullanma becerilerini ortaya koymak ve hastane bilgi sistemlerinin faydaları konusundaki görüşlerini değerlendirmektir. Araştırma Nisan 2009 tarihinde Sakarya ilinde faaliyette bulunan 11 hastanede gerçekleşmiştir. Araştırmaya 544 sağlık çalışanı katılmıştır. Veriler anket tekniği ile toplanmıştır. Verilerin analizinde tanımlayıcı istatistiksel yöntemler, Bağımsız Örneklerde $t$ Testi ve One Way ANOVA testi kullanılmıştır. Anketin güvenilirliği Cronbach Alpha katsayısına göre hesaplanmıştır. Sonuçlar\%95'likgüven aralığında, $p<0,05$ anlamlılıkdüzeyindedeğerlendirilmiştir. Çalışmanın sonuçlarına göre sağlık çalışanları kendilerini Office programları, işletim sistemleri ve bilgisayar donanımı ile hastane bilgi sistemleri kullanımında daha yetkin görmektedirler. Ayrıca sağlık çalışanları çalısstıkları bölüm için bilgi teknolojilerinin kullanımının önemli olduğunu düşünmektedirler. Daha çok kendi çalıştıkları bölümlerdeki hastane bilgi sistemleri modüllerini kullanabilmektedirler. Sağılk çalışanlarına göre hastane bilgi sistemleri daha çok bilgilere daha kolay ulaşma, tıbbi hizmetlerin daha kaliteli verilmesi, zaman kaybını önleme, çalışanlar arasında iletişimi kolaylaştırma, poliklinik hastalarına randevu verme ve hasta atamada kullanılmaktadır.
\end{abstract}

Anahtar sözcükler: Hastane bilgi sistemi, Bilgi teknolojileri, Sağlık çalısanları

\section{Abstract}

The aim of this study is to demonstrate the skills of using information technologies and hospital information systems of health employees and to evaluate their ideas about benefits of hospital information systems. Study was implemented in 11 hospitals operating in Sakarya on April 2009. 544 health employees have participated in the research. Data were collected by questionnaires. Descriptive statistical methods, independent sample t test and One Way ANOVA test were used to analyze the data. Reliability of the survey was calculated by using of Cronbach's alpha coefficient. Results were assessed in a 95\% confidence interval, $p<0.05$ significance level. According to results of the study, health employees think that they are more proficient in Office programs, operating systems, computer hardware, and the use of hospital information systems. Also, health employees think that to use information technology in their departments is important. They can use modules of hospital information systems more in their own departments. According to health employees,

* Öğr. Gör., Sakarya Üniversitesi Sağlık Hizmetleri MYO, oisik@sakarya.edu.tr

** Yrd. Doç. Dr., Sakarya Üniversitesi Sağlık Hizmetleri MYO makbolat@sakarya.edu.tr 
hospital information systems were mostly used to access information easily, provide better quality medical services, prevent time loss, facilitate communication between employees, give an appointment to outpatients to assign the patients.

Keywords: Hospital information system, Information technology, Health employees

\section{Giriş}

Etkili ve verimli bir sağlık hizmeti sunumu, ekip çalışmasını, etkili bilgi paylaşımını ve işbirliğini zorunlu kılmaktadır. Ayrıca sağlık hizmetlerinin günümüzün gelişmişlik düzeyine uygun bir şekilde sunulmasını sağlamak için standardizasyona ihtiyaç duyulmaktadır. Bunu sağlamak için sağlık hizmeti sunan kuruluşlarda bilgi teknolojileri ve enformasyon sistemlerinin kullanımı büyük önem taşımaktadır. Bilgi sistemleri bir organizasyonda o organizasyonun etkinliğini ve verimliliğini artırmak için uygulanmaktadır (Hevner, Salvatore, Jinsoo ve Sudha, 2006, s.191). Bu nedenle sağlık bilgi sisteminin amacı etkili ve yüksek kalitede hasta bakımına katkıda bulunmaktır (Haux, 2006, s.270).

19. yüzyılda pekçoktoplumyükselen sanayi ve sanayi üretimi ile karakterize edilmiştir. 20. yüzyılın ikinci yarısına kadar, verilerin işlenmesi ve iletilmesinin bilgisayarlar ve bilgisayar ağları aracılığı ile gerçekleştirilmesi fikri gelişmiştir. Günümüz, enformasyon teknolojisi ya da enformasyon toplumu çağı olarak kabul edilmektedir (Haux, Winter, Ammenwerth ve Brigl, 2004, s.2).

1950'lerde verilerin işlenmesi süreçlerinde bilgisayarların yaygın olarak kullanılmasıyla başlayan ve nispeten yeni bir disiplin olan enformasyon sistemleri, günümüzde neredeyse kaçınılmaz bir şekilde bilgisayarla donatılmakta ve kullanılan teknoloji çok karmaşık hale gelmektedir (Avison ve Elliot, 2006, s.4). Stratejik yönetim sürecinin temel parçalarından biri haline gelen bilgi teknolojileri iş alanlarını yeniden tanımlamakta ve iş dünyasını tanınmayacak derecede değiştirmektedir.

Sağlık hizmetlerinin sunumu yoğun bir enformasyon süreci içerisinde gerçekleşmektedir. Yüksek kaliteli hasta bakımı, her hastanın tıbbi geçmişinin, sunulan sağlıkhizmetinin ve hastanın iyileşme durumunun dikkatli bir şekilde belgelendirilmesini gerekli kılmaktadır (Tengilimoğlu, Işık ve Akbolat, 2009, s.345). Dolayısı ile son yıllarda sağlık kuruluşlarının çevresinde meydana gelen değişiklikler, misyonunun yeniden tanımlanmasına neden olmuştur. Ekonomik, siyasi ve sosyal açılardan örgütsel misyonlar ve amaçlar, yönetsel roller ve hatta örgüt iklimi bakımından sağlık hizmetleri paradigmasındaki değişimi görmek zor değildir (Wan, Lin ve Ma, 2002, s.127) .

\section{Bilgi Teknolojileri}

Günümüzde bilgi teknolojileri tıp ve sağlık bakımında gittikçe yaygınlaşmakta, sağlık bakımı giderek teknolojiye bağımlı hale gelmektedir. Sağlık bilgi sistemleri ve karar destek sistemleri son derece gelişmekte ve teknoloji performansı katlanarak artmaktadır. 
Ancak insanların kavrayışının gelişimi aynı hızla gerçekleşmemektedir. Bu nedenle tıpta ve sağlık bakımında insan-bilgisayar arasındaki etkileşim ve iletişim giderek önem kazanmaktadır (Aktaş, Zayim ve Saka, 2007, s.425). İleri bilgi teknolojilerinin kullanımıyla, iş süreçlerinin bütün aşamalarını gözetebilecek, özerk ve nitelikli insan kaynaklarına ihtiyaç artmaktadır (Öğüt, 2001. s.47). Bu nedenle de, bilgi teknolojilerinin kullanımıyla birlikte örgüt yapılarında, çalışanların rollerinde ve iş süreçlerinde önemli değişimler meydana gelmektedir (Kök, 2006,s.129). Dolayısıyla insan-bilgisayar etkileşimi, bilgi teknolojilerine dayalı sistemlerin daha kullanılabilir ve kullanıcının taleplerine daha uygun sistemler üretilmesi konusu ile ilgilenen multidisipliner bir alan haline geldiği söylenebilir (Aktaş, ve diğerleri, 2007, s.426). Bilgisayar kullanımı, çalışanların eğitim, teorik ve analitik bilgi elde etme ve uygulama yeteneği, farklı bir yaklaşım ve sürekli öğrenme alışkanlığı gibi yeni vasıflara sahip olmalarını gerektirmektedir (Drucker, 1995:210). Dolayısı ile bilişim teknolojilerindeki hızı gelişmeler, diğer disiplinlerde olduğu gibi sağlık alanında da büyük kazanımlar sağlayan önemli yeniliklere imkân vermiştir (Haux ve diğerleri, 2004, s.27).

Bilgi ve iletişim teknolojileri genel anlamda bilginin toplanmasını, işlenmesini, bilginini saklanmasını ve gerektiğinde herhangi bir yere iletilmesini ya da herhangi bir yerden bu bilgiye erişilmesini otomatik olarak sağlayan teknolojiler bütünü şeklinde tanımlanabilir. Bilgi sistemlerinin çalıştırılması ve geliştirilmesi multidisipliner bir konudur ve toplum ve örgütlerde stratejik, yönetsel ve operasyonel faaliyetler kapsamında enformasyon ve enformasyon teknolojilerinin toplanması, depolanması, dağıtılması ve kullanılmasına işaret etmektedir (Avison ve Elliot, 2006, s.5). Bilgi teknolojilerini sağlık sistemine uygulamak, hastaya sağlanan bakım kalitesini arttırırken maliyetleri düşürmeyi hedefler. Ancak bunu eş zamanlı sağlamak hizmet sağlayıcıları için zorlu bir durum oluşturur. Sisteme tanımlanan görevler, hastaya ait bilgilerin birimler arası olduğu kadar, farklı sistemler arasında da hareket etmesini gerektirir (Onat, 2010, s. 67).

Sağlık kuruluşlarında çeşitli maliyet azaltıcı stratejilere alternatif olarak, etkili iletişim geliştirme, verimliliği arttırma, bakımın kalitesini yükseltme, hasta ve hizmet sunucularının memnuniyetini geliştirme, hizmetlerde daha iyi performans ölçütleri sağlama ve stratejik planlamaya yardımcı olma konularında bilgi teknolojilerinin kullanımı gittikçe artmakta ve bu alanlarda büyük faydalar sağlamaktadır (Tan ve Hanna, 1994: 72; Kuperman, Spurr, Flammini, Bates ve Glaser, 2000, s.439; Wan ve diğerleri, 2002, s.130; Wang ve diğerleri, 2003, s.398; Safran, 2003, s.190; Harris, Priddin, Ruscoe, Infante ve O'toole, 2002, s.250).

\section{Hastane Bilgi Sistemleri}

Hastane bilgi sistemleri (HBS), hastane hizmetlerinin bilgisayar aracılığı ile gerçekleştirilmesi, elektronik ortamda bilgi alışverişinin otomatik olarak yapılması gibi, tıbbi, finansal ve mali hizmetler açısından ortaya çıkan detaylı bilgilerin bilgisayara dayalı bir enformasyon sistemi ile kayıt altına alınıp, bilgiye dönüştürme işlemi olarak 
tanımlanmaktadır (Köksal ve Esatoğlu, 2005, s.54). HBS, hastanenin idari ve tıbbi bilgilerinin yönetimini kolaylaştırmak ve sağlık hizmetlerinin kalitesini yükseltmek için düzenlenmiş bir bilgi sistemi olarak da tanımlanabilir. Hastanelerde bilgisayarların kullanıldığı sistemlere bilgisayara dayalı hastane bilgi sistemleri denir. İdari ve tıbbi bilgileri iç içe, bir arada tutabilen sistemlere bütünleşik HBS denilmektedir (Yılmaz ve Aloğlu, 2002, s.332).

Başlangıçta sadece doğru faturalama ve irsaliye yazııımı gereksiniminden doğan HBS, zamanla tüm hastane işlemlerini (hastanın kimlik, tetkik, muayene bilgilerinin kaydl; randevu verme; reçete ve rapor hazırlama; laboratuvar sonuçlarının aktarılması; elektronik hasta kayıtları; stok takibi; yönetim raporları; kalite verilerinin irdelenmesi; vb) kapsayan süreçlere dönüşmüştür (Rodoplu, 2007-2008, s.410). Dolayısıyla HBS'nin ana işlevi, ait olduğu kuruluşun bilgi taleplerini doğru, zamanında ve eksiksiz bir biçimde karşılamaktır. Bu kapsamda, bir hastanenin günlük rutin işlemleri (hastanın başvuru, kabul, sağlık durumu, sevk ve taburcu kayıtları gibi), hastaya yapılan tanı ve tedaviye ilişkin uygulamalar (klinik, laboratuvar, radyoloji, ameliyathane, eczane, terapi ve diyet gibi), genel yönetim işlemleri (personel, sabit tesis, cihaz ve malzeme durumu ve yönetimi gibi) ve mali (muhasebe, müşteri hesapları ve vergilendirme) işlemlerin gerçekleştirilmesinde yoğun bir şekilde kullanılmaktadır (Köksal ve Esatoğlu, 2005, s.54).

HBS'nin temel amacı bir hastanenin yönetiminde gerekli bilgilerin tam, doğru ve zamanında karşılanmasıdır. Bir hastanenin bilgi ihtiyacı, çok çeşitli alanlarda kendini göstermektedir. Bilgi sistemlerinin stratejik planlama, hizmet geliştirme ve pazarlamaya sağladığı destek ile talepler, kullanım oranları ve pazarın niteliği hakkındaki bilgilere ulaşılmaktadır. Stratejik planlama ve sürekli kalite geliştirmeye sağladığı destek ile hasta memnuniyeti; tıbbi hizmetlerin maliyeti, kalite ve etkinlik göstergelerinin takibi ile teşhis ve tedavi planlarının yapılması için uzman tıbbi veri tabanları sağlanmaktadır. Verimlilik analizi ve iyileştirme desteği ile her bir ana maliyet merkezi için belirlenmiş performans standartlarının karşılaştırılmasına, ayrıca tıp profesyonelleri ile ilişkilerin iyileştirilmesine sağladığı destek sayesinde hastane ile tıp profesyonellerinin (doktor, laboratuvar, uzman merkezler, sigorta şirketleri) arasında elektronik bağlantıların kurulmasına imkân vermektedir (Austin, Trimm ve Sobczak, 1995,s.30).

HBS içerisinde önemli bir yere sahip olan klinik bilgi sistemleri; kurum içerisinde entegrasyonu geliştirmeli, kalitenin geliştirilmesine ve verimliliğin artışına katkı sağlamalı, hasta ve hekim memnuniyetini artırmalı, hekimlerin mevcut ağ içerisinde kalmasını sağlamalı, kurumların akademik misyonuna destek olmalı ve hizmet hatlarını desteklemelidir (Kuperman ve diğerleri, 2000, s.439).

\section{Hastane Bilgi Sistemi İçinde Kullanılan Modüller}

Sağlık kuruluşları, bilgi sistemlerinden yönetim hizmetleri, hastalıkların teşhis edilmesi, hekimlerin hastayla ilgili vereceği kararların desteklenmesi, hemşire ve hekimlerin yapacağı işlerde rehberlik, sinyal yorumlama, laboratuvar hizmetleri ve hasta yönetimi 
gibi çok çeşitli alanlarda faydalanmaktadır (Özata ve Aslan, 2004, s. 12). Dolayısıyla günümüz sağlık hizmetleri sunumunda bilgisayarlar genellikle, klinik bilgi sistemleri, idari ve finansal sistemler ve karar destek sistemleri olmak üzere üç genel kategoride kullanılmaktadır (Austin ve Wager, 1998, s. 232; Tengilimoğlu ve diğerleri, 2009, s. 330).

Hastanelerin etkili ve kaliteli bir sağlık hizmeti sunabilmesi, bilgi sistemlerinin bu üç kategorisinin entegre bir şekilde kullanılmasını gerekli kılmaktadır. Bu kapsamda hastane bilgi sistemi içerisinde yer alan birçok modül bulunmaktadır. Yatan hasta, poliklinik, acil servis, doğum ve ameliyathane, anestezi reanimasyon ve yoğun bakım gibi modülleri klinik enformasyon sistemleri; laboratuvar, radyoloji, eczane, diyet, kan bankası gibi modülleri karar destek sistemleri ve ayniyat, vezne, fatura ve muhasebe, satın alma, personel ve bordro işlemleri ve istatistik gibi modüller de idari ve finansal sistemler içerisinde yer almaktadır (Ak, 2009, s. 336). Bununla birlikte Sağlık Bakanlığı ve Dünya Sağlık Örgütü arasında yapılan ve 22 Aralık 1994 tarih ve 22149 sayılı Resmi Gazete'de yayınlanan 3802TU sayılı İkinci Sağlık Projesi İkraz Anlaşması çerçevesinde devlet hastanelerinde gerçekleştirilecek HBS'nin hasta kayıt/kabul ve danışma modülü, ayakta tedavi gören hasta (poliklinik) modülü, yatan hasta modülü, laboratuvar modülü, radyoloji modülü, ameliyathane modülü, eczane modülü, depo, ambar ve demirbaş (ayniyat) modülü, vezne modülü, döner sermaye, faturalama ve muhasebe modülü, personel ve bordro işlemleri modülü ve istatistik modülünden oluşması öngörülmüştür. Bu modüllerin bütünleşik olarak çalışması amacı ile çalışmalar yapılmıştır.

\section{Türkiye'de Hastane Bilgi Sistemi}

Türk sağlık bilişimi alanında ilk çalışmalar, SSK hastanelerinde eczane bilgi sistemleri modülü uygulamaları ve sigortalılardan kesilen bilgisayar katkı payları ile başlatılmıştır. Sağlık Bakanlığı ise 1991 yılında Dünya Bankası işbirliği ile başlatılan Birinci ve 1995 yılında başlatılan ikinci Sağlık Projeleri kapsamındaki Sağlık Enformasyon Sistemleri Projesi ile Hastane Bilgi Yönetim Sistemleri çalışmalarını başlatmıştır (Ak, 2009, s.338).

Bilgisayar teknolojisi başlangıçta evrak işlemlerinin azaltılmasını ve nakit akışı ve yönetsel kararların iyileştirmesini amaçlamakta iken, daha sonraki yıllarda yatan hasta ve acil servis gibi klinik ve yardımcı servislerde elde edilen verileri de kapsamına almıştır (Köksal ve Esatoğlu, 2005, s.53). Ancak, bu alanda gerekli ve yeterli standartlar geliştirilememiştir. Hastanelerde öncelikle bilgisayar donanımının tedarik edilmesi, daha sonra bu sisteme uygun bir yazılımın satın alınmasında yazılım ve donanım bilgisi yeterli olmayan kişilerin söz sahibi olması; hastanelerde bilgi işlem sürecinde kavram kargaşası yaşanmasına neden olmaktadır (Esatoğlu ve Köksal, 2002, s. 30).

Sağlık bilgi sistemleri alanında yapılan son çalışmalar, 2003 yılı başında Sağlık Bakanlığı tarafından hazırlanan Sağlıkta Dönüşüm Programı ile başlatılmıştır. Bakanlık bu program ile karar sürecinde etkili bilgiye erişimi esas alan sağlık bilgi sisteminin de yer aldığı 8 bileşene (Şekil 1) yer vermiştir (Sağlık Bakanlığı, 2008, s.20). Günümüzde 


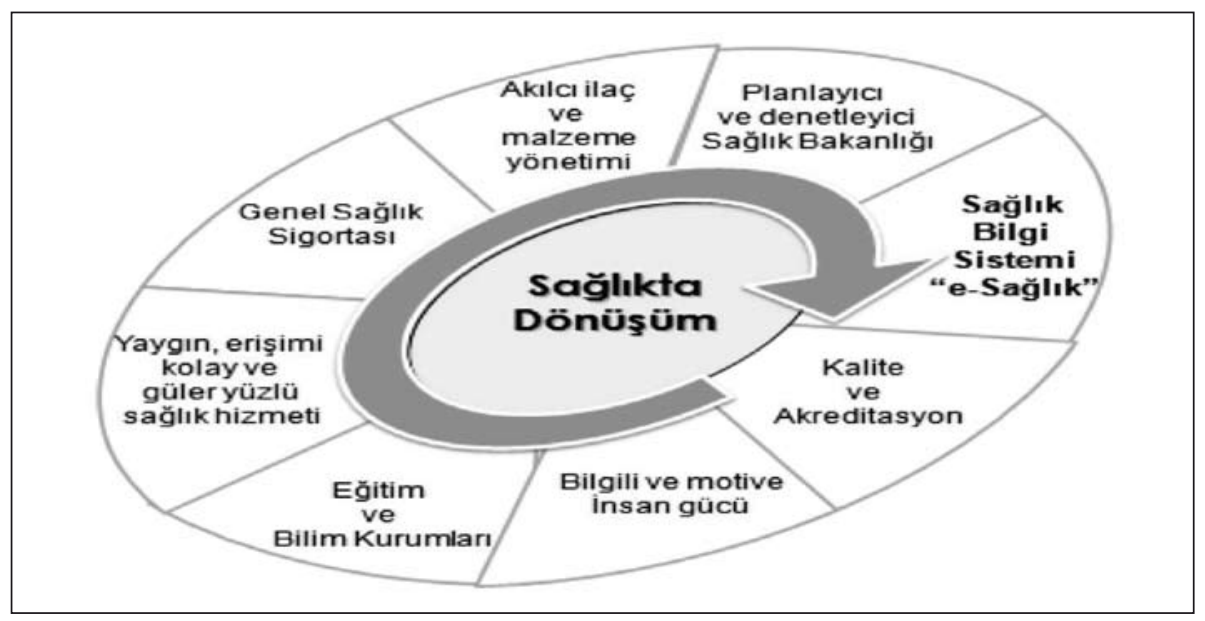

Şekil 1: Sağlıkta Dönüşüm Programı Bileşenleri

Kaynak: SB, 2008, s.20'den uyarlanmıştır.

sağlık bilgi sistemi konusunda; sağlık hizmeti verilirken iletişim kurulan kurumların standart tanımları, hizmet veren doktorların veri bankası, uluslararası olarak kabul edilmiş hastalık sınıflaması, ilaç ve tıbbi malzeme kodlamaları gibi standart kodlama sistemleri belirlenip uyumlaştırılarak sektörde kullanılmaya başlanmıştır (Sağlık Bakanlığı, 2008, s. 93). Ayrıca Sağlık Bakanlığı belirli bir standart sağlamak ve verilerin bilgiye dönüşümünün kolaylaştırmak amacıyla HBS çerçeve ilkelerini oluşturarak, kamu hastanelerinde kullanılan HBS'nin asgari düzeyde bir standarda sahip olmasını hedeflemektedir.

Son yıllarda hastane bilgi sistemi konusunda önemli gelişmeler olmasına rağmen henüz tam anlamıyla gelişmiş ülkelerin düzeyine ulaşılamamıştır. Sonuç olarak 1967 yılında başlayan sağlık bilişimi, hastane bilgi yönetim sistemi yazılımları ancak 2004 yılından sonra gelişmeye başlamıştır. Bugün HBS'nde ulaştığımız durum ABD'nin 1960 yıllarındaki düzeyindedir. Klinik karar destek sistemleri konusunda ise ABD'nin 1970'li yıllarındaki seviyesinde bulunmaktadır (Ak, 2009, s.338).

\section{Araştırmanın Amacı, Kapsamı ve Yöntemi}

Giriş bölümünde belirtildiği gibi, araştırmanın amacı, sağlık çalışanlarının bilgi teknolojileri ve hastane bilgi sistemi kullanım becerilerini ve hastane bilgi sisteminin sağlık kuruluşlarına sağladığı faydalara ilişkin düşüncelerini ortaya koymaktır. Araştırmada yeterli sayıda anket elde edilememesi nedeni ile hekim grubu ve sayıları sınırlı olduğundan fizyoterapist, diyetisyen, psikolog vb, personel araştırma kapsamına alınmamıştır. Bu nedenle araştırma hastane bilgi sistemlerini yoğun bir şekilde kullanan 
hemşire/ebe, sağlık memuru, tıbbi tekniysen/tekniker ve tıbbi sekreter ve memurlar ile kısıtlandırılmıştır.

Araştırmanın evrenini 8'i kamu ve 3'ü özel olmak üzere Sakarya İli'nde faaliyet gösteren 11 hastanede çalışan hemşire/ebe, sağlık memuru, tıbbi tekniysen/tekniker ve tıbbi sekreter ve memurlardan oluşan 1748 kişi oluşturmaktadır. Araştırmada rastgele tabakalı örneklem seçimi yöntemi kullanılmış olup; örneklem seçiminde aşağıdaki formülden yararlanılmıştır (Bal 2001: 113-114; Güredin 1987: 368-370).

$$
n^{1}=\frac{N \times p \times p \times Z^{2}}{\left[(N-1) \times t^{2}\right]+\left(p \times q \times Z^{2}\right)}
$$

Formüle göre \%95 güven aralığında evreni temsil edecek örneklem büyüklüğü 315'dir. Ancak araştırmada 750 anket dağıtılmış olup, bu anketlerden 572'sinin dönüşü sağlanabilmiş ve dönen anketlerden 544'ünün analize uygun olduğuna karar verilmiştir. Bu sonuca göre dağıtılan anketlerin ancak \%72,53'ü değerlendirilebilmiştir. Çalışma 130 Nisan 2009 tarihleri arasında yapılmıştır. Araştırmada kullanılan evren ve örneklemle ilgili ayrıntılı bilgi Tablo I'de görülmektedir.

Araştırmanın amacına uygun olan literatürden yararlanılarak, sağlık çalışanlarının bilgi sistemini kullanım becerilerini ve kullanılan sistemin fayda sağladığı alanları ortaya çıkaracak bir anket geliştirilmiştir. Ankette, sağlık çalışanlarını tanımlayıcı bilgilerin yanı sıra, bilgi teknolojileri ile ilgili bilgi düzeylerini ölçen 11, bilgi sisteminin faydaları konusunda 19 ve hastane bilgi sistemi kullanım becerileri ile ilgili 19 soru bulunmaktadır.

Tablo I. Araştırmada Kullanılan Evren ve Örneklem

\begin{tabular}{|c|c|c|c|c|c|c|c|c|}
\hline & \multicolumn{3}{|c|}{ Evren } & \multirow{2}{*}{$\begin{array}{l}\text { Örneklem } \\
\text { Ağırlığı }\end{array}$} & \multirow{2}{*}{$\begin{array}{c}\text { Örneklem } \\
\text { Sayısı }\end{array}$} & \multirow{2}{*}{$\begin{array}{c}\text { Dağıtılan } \\
\text { Anket } \\
\text { Sayısı }\end{array}$} & \multirow{2}{*}{$\begin{array}{l}\text { Dönen } \\
\text { Anket } \\
\text { sayısı }\end{array}$} & \multirow{2}{*}{$\begin{array}{c}\text { Kullanılan } \\
\text { Anket } \\
\text { sayısı }\end{array}$} \\
\hline & Kamu & Özel & Toplam & & & & & \\
\hline Hemşire/Ebe & 773 & 119 & 892 & 0,51 & 161 & 315 & 170 & 162 \\
\hline Sağlık Memuru & 99 & 8 & 107 & 0,06 & 19 & 55 & 50 & 47 \\
\hline $\begin{array}{l}\text { Sağ.Teknis/ } \\
\text { Teknikeri }\end{array}$ & 213 & 58 & 271 & 0,16 & 49 & 70 & 52 & 40 \\
\hline Tıbbi Sekreter & 203 & 93 & 296 & 0,17 & 53 & 200 & 195 & 192 \\
\hline Memur & 182 & 0 & 182 & 0,10 & 33 & 110 & 105 & 103 \\
\hline Toplam & 1470 & 278 & 1748 & 100 & 315 & 750 & 572 & 544 \\
\hline
\end{tabular}

Formülde; $N=$ Evren, $n$ = Örneklem sayısı, $p=$ Evren içinde ilgilendiğimiz özelliğin görülme sıklığı (0,50 alınmıştır), $q=$ Evren içinde ilgilendiğimiz özelliğin görülmeme sıklığı (1-p), Z = Güven düzeyine göre standart değer (normal dağılım tablolarından bulunur $\% 95$ için 1,96$)$ ve $t=$ Göz yumulabilir yanılgı $(0,05$ alınmıştır). 
Anket sonucu elde edilen veriler SPSS paket programı kullanılarak analiz edilmiştir. Elde edilen verilerin homojenite testleri yapılmış olup veriler parametrik özellik gösterdiğinden; verilerin analizinde Bağımsız Örneklerde t Testi ve One Way ANOVA kullanılmıştır. One Way ANOVA testi sonucunda ortaya çıkan farklılıkların tespitinde Tukey ve LSD testleri kullanılmıştır. Anketin güvenilirliği Cronbach Alpha katsayısına göre hesaplanmıştır. Çalışma sonucunda elde edilen verilerin Cronbach Alpha değeri 0,961 olarak bulunmuştur. Bu değer anketin yüksek düzeyde güvenilir olduğunu gösterdiğinden (Altunışık, Coşkun, Bayraktaroğlu ve Yıldırım, 2005) çalışmanın yapılmasına karar verilmiştir. Sonuçlar \%95'lik güven aralığında, $p<0,05$ anlamlılık düzeyinde değerlendirilmiştir.

\section{Bulgular}

\section{Tanımlayıcı Bulgular}

Araştırmaya katılan sağlık çalışanlarının, \%68,9'u kadın ve \%52,8'i evlidir. Katılımcıların \%35,3'ü tıbbi sekreter, \%29,8'i hemşire, \%8,6'sı sağlık memuru, \%18,9'u memur ve \%7,4'ü sağlık teknisyeni/teknikeri olarak görev yapmaktadır. Çalışmaya katılan sağlık çalışanlarının büyük bir bölümü $\leq 10$ yıldır $(\% 70,8)$ çalışmakta olup, buna paralel olarak daha genç çalışanlardan oluşmaktadırlar. Daha çok lise $(\% 45,4)$ ve önlisans $(\% 39,2)$ mezunlarından oluşan katılımcıların \%12,7'si lisans ve \%2,8'i lisansüstü seviyede eğitim almıştır. Büyük bir bölümü gündüz mesai saatleri içinde çalışan $(\% 68,4)$ katılımcıların \%36,4'ü memur, \%20,2'si sözleşmeli ve \%43,4'ü şirket elemanı olarak istihdam edilmiştir. \%62,1'i tıbbi birimlerde (klinik, poliklinik, kan bankası, laboratuvar vb) çalışan katılımcıların \%81,8'i herhangi bir şekilde HBS konusunda eğitim aldıklarını bildirmiştir (Tablo II).

\section{Katılımcıların Bilgi Teknolojileri ve Hastane Bilgi Sistemleri Eğitimi ve Kullanımına İlişkin Bulgular}

Araştırmaya katılan sağlık çalışanlarının bilgi teknolojileri hakkında bilgi düzeylerinin değerlendirilmesi sonucunda; \%61,8'inin Office programları, \%61,2'sinin işletim sistemleri ve \%59,2'sinin bilgisayar donanımı konusunda kendilerini yeterli gördükleri bulunmuştur. Buna karşılık veri tabanı $(\% 37,1)$, ağ sistemleri $(\% 40,3)$ ve ses kayıt dinleme cihazları konusunda $(\% 40,4)$ bilgi düzeylerini daha yetersiz görmektedirler (Tablo III). 
Tablo II. Sağlık Çalışanlarının Tanımlayıcı Özelliklerinin Dağıımı

\begin{tabular}{|c|c|c|c|c|c|c|c|}
\hline & & Sayı & $\%$ & & & Sayı & $\%$ \\
\hline \multirow{2}{*}{ Cinsiyet } & Erkek & 169 & 31,1 & \multirow{2}{*}{ Medeni durum } & Evli & 287 & 52,8 \\
\hline & Kadın & 375 & 68,9 & & Bekar & 257 & 47,2 \\
\hline \multirow{5}{*}{$\begin{array}{l}\text { Görev } \\
\text { Ünvanı }\end{array}$} & Tıbbi sekreter & 192 & 35,3 & \multirow{5}{*}{ Çalışma süresi } & $\leq 4 \mathrm{yll}$ & 254 & 46,7 \\
\hline & Hemşire/ebe & 162 & 29,8 & & $5-9$ yıl & 131 & 24,1 \\
\hline & Sağlık Memuru & 47 & 8,6 & & 10-14 yıl & 58 & 10,7 \\
\hline & Memur & 103 & 18,9 & & 15-19 yıl & 38 & 7,0 \\
\hline & Sağlık tek. & 40 & 7,4 & & $\geq 20 \mathrm{yll}$ & 63 & 11,6 \\
\hline \multirow{4}{*}{ Yaş } & $\leq 24$ & 157 & 28,9 & \multirow{4}{*}{ Eğitim durumu } & Lise & 247 & 45,4 \\
\hline & $25-34$ & 267 & 49,1 & & Önlisans & 213 & 39,2 \\
\hline & $35-44$ & 82 & 15,1 & & Lisans & 69 & 12,7 \\
\hline & $\geq 45$ & 38 & 7,0 & & Lisansüstü & 15 & 2,8 \\
\hline \multirow{3}{*}{$\begin{array}{l}\text { Çalışma } \\
\text { Şekli }\end{array}$} & Gündüz & 372 & 68,4 & \multirow{3}{*}{ İstihdam şekli } & Memur & 198 & 36,4 \\
\hline & Nöbet & 75 & 13,8 & & Sözleşmeli & 110 & 20,2 \\
\hline & Vardiya & 97 & 17,8 & & Şirket elemanı & 236 & 43,4 \\
\hline \multirow{2}{*}{$\begin{array}{l}\text { Çalışılan } \\
\text { birim }\end{array}$} & İdari birimler & 206 & 37,9 & \multirow{2}{*}{$\begin{array}{l}\text { Bilgi sistemleri } \\
\text { konusunda } \\
\text { eğitim }\end{array}$} & Alan & 445 & 81,8 \\
\hline & Tıbbi birimler & 338 & 62,1 & & Almayan & 99 & 18,2 \\
\hline
\end{tabular}

Tablo III. Sağlık Çalışanlarının Bilgi Teknoloji Kullanım Düzeyleri

\begin{tabular}{lcccccc}
\hline & \multicolumn{2}{c}{ Yeterli } & \multicolumn{2}{c}{ Kısmen yeterli } & \multicolumn{2}{c}{ Yetersiz } \\
\cline { 2 - 7 } & Sayı & $\%$ & Sayı & $\%$ & Sayı & $\%$ \\
\hline Office programları (Word, Excel vb.) & 336 & 61,8 & 118 & 21,7 & 90 & 16,5 \\
Bilgisayar işletim sistemleri & 333 & 61,2 & 128 & 23,5 & 83 & 15,3 \\
Bilgisayar donanımı & 322 & 59,2 & 146 & 26,8 & 76 & 14,0 \\
Fotokopi ve baskı makinesi & 310 & 57,0 & 117 & 21,5 & 117 & 21,5 \\
Bilgisayar yazılımları & 279 & 51,3 & 153 & 28,1 & 112 & 20,6 \\
Tele-Sekreter & 225 & 41,4 & 110 & 20,2 & 209 & 38,4 \\
Ses kayıt veya dinleme cihazı & 220 & 40,4 & 107 & 19,7 & 217 & 39,9 \\
Network (bilgisayar ağları) & 219 & 40,3 & 141 & 25,9 & 184 & 33,8 \\
Veritabanı (Java,Oracle, Access) & 202 & 37,1 & 149 & 27,4 & 193 & 35,5 \\
\hline
\end{tabular}


Tablo IV. Sağlık Çalışanlarının Hastane Bilgi Sistemi Konusunda Yeterlilik Düzeyleri

\begin{tabular}{|c|c|c|c|c|c|c|c|c|c|c|c|c|c|}
\hline \multirow{2}{*}{\multicolumn{2}{|c|}{ Özellikler }} & \multicolumn{2}{|c|}{$\begin{array}{l}\text { Kesinlik. } \\
\text { yetersiz }\end{array}$} & \multicolumn{2}{|c|}{ Yetersiz } & \multicolumn{2}{|c|}{$\begin{array}{c}\text { Kısmen } \\
\text { yeterli }\end{array}$} & \multicolumn{2}{|c|}{ Yeterli } & \multicolumn{2}{|c|}{$\begin{array}{c}\text { Kesinlik. } \\
\text { yeterli }\end{array}$} & & \multirow[t]{2}{*}{$\mathbf{p}$} \\
\hline & & Sayı & $\%$ & Sayı & $\%$ & Sayı & $\%$ & Sayı & $\%$ & Sayı & $\%$ & & \\
\hline Genel Yeterlilik S & Seviyesi & 25 & 4,6 & 64 & 11,8 & 127 & 23,3 & 198 & 36,4 & 130 & 23,9 & - & - \\
\hline \multirow{2}{*}{ Medeni durum } & Evli & 17 & 5,9 & 39 & 13,6 & 77 & 26,8 & 96 & 33,4 & 58 & 20,2 & \multirow{2}{*}{12,12} & \multirow{2}{*}{0,017} \\
\hline & Bekâr & 8 & 3,1 & 25 & 9,7 & 50 & 19,5 & 102 & 39,7 & 72 & 28,0 & & \\
\hline \multirow{5}{*}{ Görev Unvanı } & Tıbbi sekreter & 4 & 2,1 & 15 & 7,8 & 35 & 18,2 & 69 & 35,9 & 69 & 35,9 & \multirow{5}{*}{48,91} & \multirow{5}{*}{0,000} \\
\hline & Hemşire & 15 & 9,3 & 22 & 13,6 & 45 & 27,8 & 54 & 33,3 & 26 & 16,0 & & \\
\hline & Sağ. Memuru & 1 & 2,1 & 8 & 17,0 & 14 & 29,8 & 19 & 40,4 & 5 & 10,6 & & \\
\hline & Memur & 1 & 1,0 & 12 & 11,7 & 23 & 22,3 & 45 & 43,7 & 22 & 21,4 & & \\
\hline & Sağlık tek. & 4 & 10,0 & 7 & 17,5 & 10 & 25,0 & 11 & 27,5 & 8 & 20,0 & & \\
\hline \multirow{4}{*}{ Eğitim durumu } & Lise & 9 & 3,6 & 26 & 10,5 & 63 & 25,5 & 95 & 38,5 & 54 & 21,9 & \multirow{4}{*}{32,87} & \multirow{4}{*}{0,001} \\
\hline & Önlisans & 6 & 2,8 & 28 & 13,1 & 43 & 20,2 & 72 & 33,8 & 64 & 30,0 & & \\
\hline & Lisans & 6 & 8,7 & 7 & 10,1 & 19 & 27,5 & 26 & 37,7 & 11 & 15,9 & & \\
\hline & Lisansüstü & 4 & 26,7 & 3 & 20,0 & 2 & 13,3 & 5 & 33,3 & 1 & 6,7 & & \\
\hline \multirow{5}{*}{ Çalışma süresi } & $\leq 5 \mathrm{yll}$ & 11 & 4,3 & 19 & 7,5 & 49 & 19,3 & 95 & 37,4 & 80 & 31,5 & \multirow{5}{*}{34,44} & \multirow{5}{*}{0,005} \\
\hline & $5-9$ yıl & 6 & 4,6 & 15 & 11,5 & 35 & 26,7 & 46 & 35,1 & 29 & 22,1 & & \\
\hline & 10-14 yıl & 3 & 5,2 & 8 & 13,8 & 20 & 34,5 & 20 & 34,5 & 7 & 12,1 & & \\
\hline & 15-19 yıl & 2 & 5,3 & 8 & 21,1 & 8 & 21,1 & 12 & 31,6 & 8 & 21,1 & & \\
\hline & $\geq 20$ yıl & 3 & 4,8 & 14 & 22,2 & 15 & 23,8 & 25 & 39,7 & 6 & 9,5 & & \\
\hline \multirow{3}{*}{ İstihdam şekli } & Memur & 11 & 5,6 & 32 & 16,2 & 53 & 26,8 & 75 & 37,9 & 27 & 13,6 & \multirow{3}{*}{26,64} & \multirow{3}{*}{0,001} \\
\hline & Sözleşmeli & 7 & 6,4 & 8 & 7,3 & 28 & 25,5 & 40 & 36,4 & 27 & 24,5 & & \\
\hline & $\begin{array}{l}\text { Şirket ele- } \\
\text { manı }\end{array}$ & 7 & 3,0 & 24 & 10,2 & 46 & 19,5 & 83 & 35,2 & 76 & 32,2 & & \\
\hline \multirow{3}{*}{ Çalışma şekli } & Gündüz & 11 & 3,0 & 36 & 9,7 & 80 & 21,5 & 139 & 37,4 & 106 & 28,5 & \multirow{3}{*}{25,84} & \multirow{3}{*}{0,001} \\
\hline & Nöbet & 6 & 8,0 & 13 & 17,3 & 18 & 24,0 & 24 & 32,0 & 14 & 18,7 & & \\
\hline & Vardiya & 8 & 8,2 & 15 & 15,5 & 29 & 29,9 & 35 & 36,1 & 10 & 10,3 & & \\
\hline \multirow{2}{*}{ Çalışılan birim } & İdari & 3 & 1,5 & 23 & 11,2 & 44 & 21,4 & 83 & 40,3 & 53 & 25,7 & \multirow{2}{*}{9,62} & 0,047 \\
\hline & Tibbi & 22 & 6,5 & 41 & 12,1 & 83 & 24,6 & 115 & 34,0 & 77 & 22,8 & & \\
\hline Bilgi sistemleri & Alan & 15 & 3,4 & 48 & 10,8 & 94 & 21,1 & 169 & 38,0 & 119 & 26,7 & 510 & 0000 \\
\hline eğitimi & Almayan & 10 & 10,1 & 16 & 16,2 & 33 & 33,3 & 29 & 29,3 & 11 & 11,1 & & \\
\hline
\end{tabular}

Sağlık çalışanları hastane bilgi sistemi kullanımı konusunda kendilerini $\% 16,4$ oranında kesinlikle yetersiz ve yetersiz bulurken, $\% 60,3$ 'ü yeterli ve kesinlikle yeterli bulmaktadır. Kendilerini kısmen yeterli gören sağlık çalışanı oranı ise $\% 23,3$ 'tür. Sağlık 
çalışanların sosyo demografik özellikleri esas alınarak yapılan Ki-Kare analizi sonucunda ise sağlık çalışanlarının yaş ve cinsiyetleri ile HBS kullanımı arasında istatistiksel açıdan anlamlı ilişki bulunmamıştır ( $p>0,05)$. Buna karşııık sağlık çalışanlarının medeni durumu, unvanı, eğitim durumu, çalışma süresi, istihdam şekli, çalışma şekli, çalıştığı birim ve bilgi sistemi eğitimi alma durumu ile HBS kullanım yeterliliği arasında istatistiksel olarak anlamlı ilişki bulunmuştur $(p<0,05)$. Anlamlı ilişki bulunan özellikler ile ilgili ayrıntılar Tablo IV'de verilmiştir.

Tablo V. Sağlık Çalışanlarının Hastane Bilgi Sistemi Konusunda Aldıkları Eğitimin Türünün Çapraz Olarak Karşılaştırılması $(n=445)$

\begin{tabular}{lrrrrrrrrrr}
\hline \multirow{2}{*}{ Eğitim Türü } & \multicolumn{2}{c}{ Örgün } & \multicolumn{2}{c}{ Seminer } & \multicolumn{2}{c}{ Kurs } & \multicolumn{2}{c}{ Sertifika } & \multicolumn{2}{c}{ Hizmet içi } \\
\cline { 2 - 10 } & Sayı & \multicolumn{1}{c}{$\%$} & \multicolumn{1}{c}{ Sayı } & $\%$ & Sayı & $\%$ & Sayı & $\%$ & Sayı & $\%$ \\
\hline Örgün & $\mathbf{5 7}$ & $\mathbf{1 2 , 8}$ & & & & & & & & \\
Seminer & 5 & 1,1 & $\mathbf{1 0 1}$ & $\mathbf{2 2 , 7}$ & & & & & & \\
Kurs & 4 & 0,9 & 16 & 3,6 & $\mathbf{5 1}$ & $\mathbf{1 1 , 5}$ & & & & \\
Sertifika & 6 & 1,3 & 22 & 4,9 & 10 & 2,2 & $\mathbf{6 5}$ & $\mathbf{1 4 , 6}$ & & \\
Hizmet içi & 12 & 2,7 & 41 & 9,2 & 20 & 4,5 & 29 & 6,5 & $\mathbf{2 8 6}$ & $\mathbf{6 4 , 3}$ \\
\hline
\end{tabular}

Tablo V'de görüldüğü gibi, sağlık çalışanlarının \%12,8'i örgün öğretim, \%22,7'si seminer, \%11,5'i kurs, \%14,6'sı sertifika programları ve \%64,3'ü hizmet içi eğitim yoluyla HBS konusunda eğitim almıştır. Ayrıca birden fazla eğitim alan sağlık çalışanları da aynı tabloda verilmiştir. Buna göre en fazla eğitim hem hizmet içi eğitim, hem de seminerlere $(\% 9,2)$ katılanlarda görülmektedir. En az katılım ise hem örgün öğretim görüp hem de kurslara katılanlarda $(\% 0,9)$ görülmektedir.

Sağlık çalışanlarının \%52,4'ü çalıştıkları bölüm için bilgi teknolojilerinin kullanımının çokönemli, \%22,2 ise önemli olduğunu düşünmektedir. Buna karşılık, sağlıkçalışanlarının \%12,2'si çalıştıkları birimde bilgi teknolojisinin kullanılmasını kesinlikle önemsiz ve $\% 5,1$ 'i önemsiz bulmaktadır (Tablo VI).

Tablo VI. Çalışılan Bölümde Bilgi Teknolojileri Kullanımının Önemine Sağlık Çalışanlarının Katılımı ( $n=544)$

\begin{tabular}{lcc}
\hline & $\mathbf{n}$ & $\%$ \\
\hline Kesinlikle Katılıyorum & 285 & 52,4 \\
Katılıyorum & 121 & 22,2 \\
Kısmen Katılıyorum & 44 & 8,1 \\
Katılmıyorum & 28 & 5,1 \\
Kesinlikle Katılmıyorum & 66 & 12,1 \\
\hline
\end{tabular}


Tablo VII. Sağlık Çalışanlarının Hastane Bilgi Sistemi Modülleri Kullanabilme Oranları

\begin{tabular}{llllc}
\hline & \multicolumn{2}{c}{ Kullanabilen } & \multicolumn{2}{c}{ Kullanamayan } \\
\hline & Sayı & $\%$ & Sayı & $\%$ \\
\hline Hasta kayıt kabul-danışma modülü & 357 & 65,6 & 187 & 34,4 \\
Ayakta tedavi gören hasta (poliklinik) modülü & 325 & 59,7 & 219 & 40,3 \\
Ağız ve diş sağlığı modülü & 170 & 50,4 & 374 & 68,8 \\
Acil servis modülü & 274 & 48,3 & 270 & 49,6 \\
Yatan hasta modülü & 263 & 38,2 & 281 & 51,7 \\
Doğum ve ameliyathane modülü & 146 & 34,9 & 398 & 73,2 \\
Anestezi, reanimasyon ve yoğun bakım modülü & 118 & 32,7 & 426 & 78,3 \\
Laboratuvar modülü & 190 & 31,3 & 354 & 65,1 \\
Radyoloji (tıbbi görüntüleme işlemleri) modülü & 178 & 30,3 & 366 & 67,3 \\
Eczane modülü & 150 & 28,5 & 394 & 72,4 \\
Diyet modülü & 109 & 27,6 & 435 & 80,0 \\
Kan merkezi modülü & 145 & 27,4 & 399 & 73,3 \\
Depo, ambar ve demirbaş (ayniyat) modülü & 165 & 27,0 & 379 & 69,7 \\
Vezne modülü & 208 & 26,8 & 336 & 61,8 \\
Döner sermaye, faturalama ve muhasebe modülü & 147 & 26,7 & 397 & 73,0 \\
Personel ve bordro işlemleri modülü & 149 & 24,1 & 395 & 72,6 \\
Satın alma modülü & 131 & 23,7 & 413 & 75,9 \\
Cihaz takip modülü & 129 & 21,7 & 415 & 76,3 \\
İstatistik modülü & 20,0 & 389 & 71,5 \\
\hline & & & & \\
\hline
\end{tabular}

Tablo VII'de görüldüğü gibi, araştırmaya katılan sağlık çalışanlarının en çok kullanabildikleri hastane bilgi sistemi modülleri, hasta kayıt kabul-danışma modülü $(\% 65,6)$, ayakta tedavi gören hasta modülü $(\% 59,7)$, ağız ve diş sağlığı modülü $(\% 50,4)$ ve acil servis modülüdür $(\% 48,3)$. Kullanım oranları en düşük olan HBS modülleri ise istatistik modülü $(\% 20,0)$, cihaz takip modülü $(\% 21,7)$, satın alma modülü $(\% 23,7)$ ve personel ve bordro işlemleri modülüdür $(\% 24,1)$. 


\section{Hastane Bilgi Sistemi Kullanımının Faydaları Konusundaki Bulgular}

Ayrıntılı bir şeklide Tablo VIII'de görüldüğü gibi, çalışmaya katılan sağlık çalışanlarına göre HBS'nin kullanılması, bilgilere daha kolay ulaşma $(4,18 \pm 1,213)$, tıbbi hizmetlerin daha kaliteli verilmesi $(3,99 \pm 1,316)$ ve zaman kaybını önlemede $(3,95 \pm 1,303)$ daha faydalıdır. Buna karşılık en az yarar sağladığı alanlar envanter kontrolü $(3,42 \pm 1,763)$, hasta bakımının planlanması $(3,46 \pm 1,660)$ ve bilgisayar destekli tıbbi karar almadadır $(3,57 \pm 1,671)$.

Ayrıca, sağlık çalışanlarının görüşlerine göre HBS, bilgilere daha kolay ulaşma, tıbbi hizmetlerin daha kaliteli verilmesi, zaman kaybını önleme, çalışanlar arasında iletişimi kolaylaştırma, poliklinik hastalarına randevu verme ve hasta atama, kalite yönetimine destek olma, malzeme sipariş ve takibinin daha etkili yapılması, malzeme ihtiyaçlarının daha etkili planlanması, laboratuvar testlerinin analizi, tıbbi görüntülerin analizi, maliyetleri azaltma ve ilaç ve diğer tıbbi cihaz ve sarf malzemelerinin takibine yüksek seviyede fayda sağlamaktadır. Buna karşılık, bordro hazırlama ve hesap çıkarma, çalışanların performansının ölçülmesi, ameliyathane ve tanı ünitelerini daha etkili planlama, doktor istem ve tedavi sonuçlarının girişi, bilgisayar destekli tıbbi karar alma, hasta bakımının planlanması ve envanter kontrolünde ise orta düzeyde katkı sağladığını düşünmektedirler. Tablo VIII'de de görüldüğü gibi hastane bilgi sistemi kullanımının faydaları hakkındaki ifadelere düşük seviyede katılım olmamıştır.

Hastane bilgi sistemi kullanımının sağladığı faydaların analizinde verilerin homojen olup olmadığını analiz etmek için homojenite testi yapılmış olup, verilerin homojen olduğu görüldüğünden verilerin analizinde Bağımsız örneklerde $t$ Testi ve Tek Yönlü Varyans Analizi testi kullanılmıştır. Yapılan analiz sonucunda eğitim durumu, çalışma süresi ve istihdam şekli bakımından çalışanlar arasında istatistiksel açıdan anlamlı fark bulunmamıştır ( $p>0,05)$. 


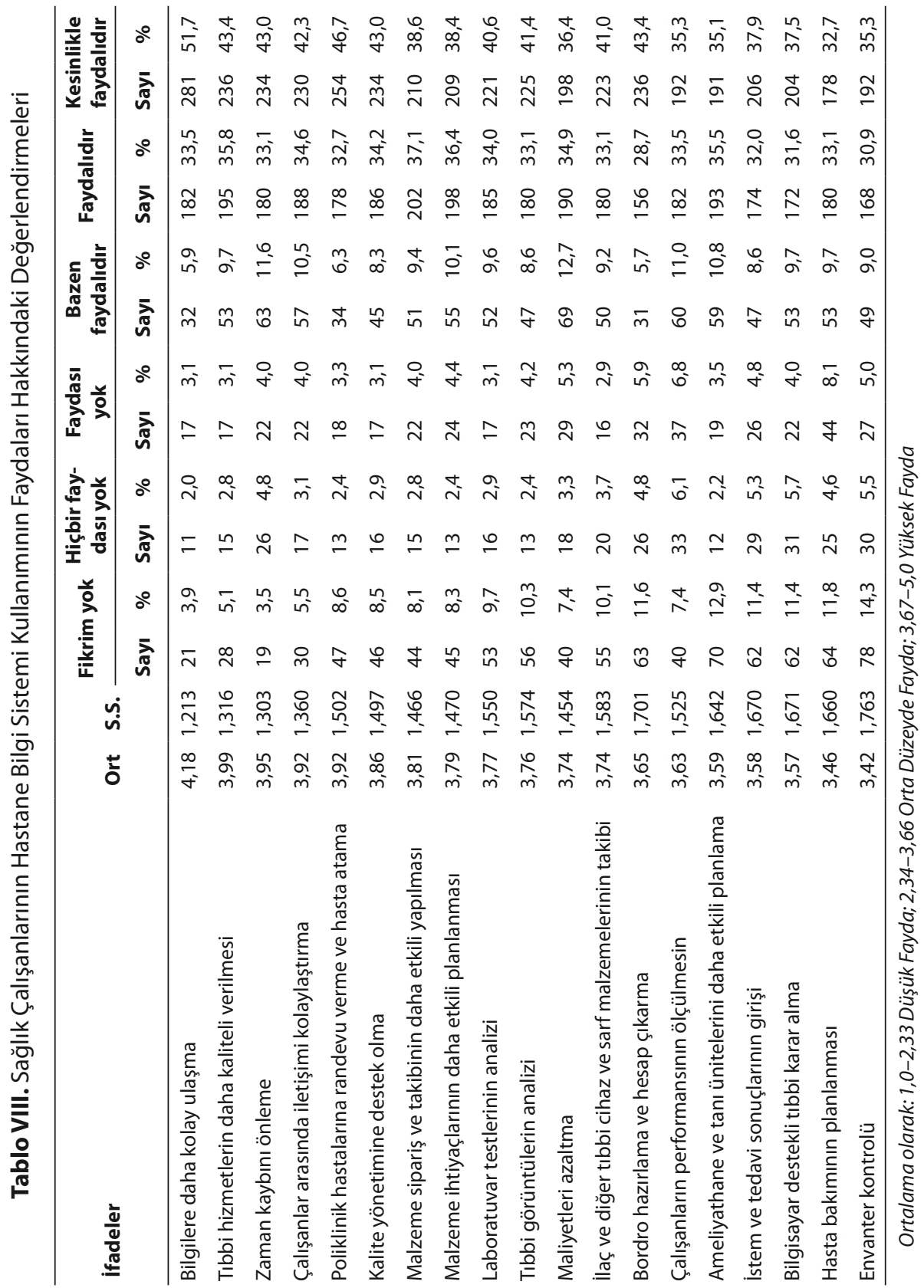


Sağlık çalışanlarının cinsiyetlerine göre yapılan analizde poliklinik hastalarına randevu verme ve hasta atama $(p=0,026)$, envanter kontrolü $(p=0,005)$ ve bordro hazırlama ve hesap çıkarma $(p=0,032)$ ifadelerinde istatistiksel açıdan anlamlı fark bulunmuştur. Envanter kontrolü ve bordro hazırlama ve hesap çıkarma ifadelerinde erkek çalışanların katılımı daha yüksek olmasına karşılık, poliklinik hastalarına randevu verme ve hasta atama ifadesinde ise kadın çalışanların katılımı daha yüksektir (Tablo IX).

Tablo IX. Sağlık Çalışanlarının Hastane Bilgi Sistemi Kullanımının Faydaları İle İlgili Değerlendirmelerinin Cinsiyetlerine Göre Dağılımı

\begin{tabular}{lcccccc}
\hline & Cinsiyet & n & Ort. & S.S & t & p \\
\hline $\begin{array}{lllllll}\text { Poliklinik hastalarına randevu verme ve } \\
\text { hasta atama }\end{array}$ & Erkek & 169 & 3,8 & 1,570 & & \\
& Kadın & 375 & 4,0 & 1,468 & & \\
\hline & Erkek & 169 & 3,6 & 1,617 & & \\
Envanter kontrolü & Kadın & 375 & 3,4 & 1,822 & & 0,005 \\
& Erkek & 169 & 3,7 & 1,582 & & \\
Bordro hazırlama ve hesap çıkarma & Kadın & 375 & 3,6 & 1,754 & & 0,032 \\
\hline
\end{tabular}

Sağlık çalışanlarının medeni durumlarına göre yapılan analizde poliklinik hastalarına randevu verme ve hasta atama $(p=0,017)$, ilaç ve diğer tıbbi cihaz ve sarf malzemelerinin takibi $(p=0,013)$ ifadelerinde istatistiksel açıdan anlamlı fark bulunmuştur. Her iki ifadeye de bekâr sağlık çalışanlarının katılımı daha yüksek olmuştur (Tablo X).

Tablo X. Sağlık Çalışanlarının Hastane Bilgi Sistemi Kullanımının Faydaları İle İlgili Değerlendirmelerinin Medeni Durumlarına Göre Dağılımı

\begin{tabular}{lcccccc}
\hline & Medeni durum & n & Ort. & S.S & t & p \\
\hline $\begin{array}{l}\text { Poliklinik hastalarına randevu } \\
\text { verme ve hasta atama }\end{array}$ & Evli & 287 & 3,83 & 1,582 & & \\
& Bekâr & 257 & 4,02 & 1,404 & & 0,017 \\
\hline $\begin{array}{l}\text { Ilaç ve diğer tıbbi cihaz ve sarf } \\
\text { malzemelerinin takibi }\end{array}$ & Evli & 287 & 3,65 & 1,663 & & \\
& Bekâr & 257 & 3,85 & 1,486 & & 0,013 \\
\hline
\end{tabular}


Tablo XI. Sağlık Çalışanlarının Hastane Bilgi Sistemi Kullanımının Faydaları İle İlgili Değerlendirmelerinin Yaşlarına Göre Dağılımı

\begin{tabular}{lcrrrrrc}
\hline & & n & Ort. & S.S. & F & p & Post Hoc. \\
\hline \multirow{2}{*}{$\begin{array}{l}\text { Ilaç ve diğer tıbbi cihaz } \\
\text { ve sarf malzemelerinin }\end{array}$} & $254^{1}$ & 157 & 3,55 & 1,726 & & & \\
takibi & $35-44^{2}$ & 267 & 3,97 & 1,447 & & & $1-2$ \\
& $\geq 45^{4}$ & 38 & 3,45 & 1,572 & & & \\
\hline & $\leq 24^{1}$ & 157 & 3,17 & 1,791 & & & \\
Hasta bakımının & $25-34^{2}$ & 267 & 3,64 & 1,575 & & & $1-2$ \\
planlanması & $35-44^{3}$ & 82 & 3,40 & 1,654 & 2,660 & 0,048 & $\mathrm{p}=0,027$ \\
& $\geq 45^{4}$ & 38 & 3,53 & 1,589 & & & \\
\hline & $\leq 24^{1}$ & 157 & 3,11 & 1,947 & & & \\
Envanter kontrolü & $25-34^{2}$ & 267 & 3,61 & 1,633 & & & $1-2$ \\
& $35-44^{3}$ & 82 & 3,39 & 1,769 & 2,763 & 0,041 & $\mathrm{p}=0,022$ \\
& $\geq 45^{4}$ & 38 & 3,47 & 1,704 & & & \\
\hline & $\leq 24^{1}$ & 157 & 3,34 & 1,890 & & & \\
Bordro hazırlama ve & $25-34^{2}$ & 267 & 3,86 & 1,565 & & & $1-2$ \\
hesap çıkarma & $35-44^{3}$ & 82 & 3,61 & 1,720 & 3,162 & 0,024 & $\mathrm{p}=0,013$ \\
& $\geq 45^{4}$ & 38 & 3,55 & 1,606 & & & \\
\hline
\end{tabular}

Sağlık çalışanlarının yaşı esas alınarak yapılan analizde ilaç ve diğer tıbbi cihaz ve sarf malzemelerinin takibi $(p=0,015)$, hasta bakımının planlanması $(p=0,048)$, envanter kontrolü $(p=0,041)$, bordro hazırlama ve hesap çıkarma $(p=0,024)$ ifadelerinde istatistiksel açıdan anlamlı fark bulunmuştur. Ifadelerin tamamında fark $\leq 24$ yaş sağlık çalışanları ile 25-34 yaşlardaki sağlık çalışanlarından kaynaklanmaktadır ( $p<0,05)$. Ifadelerin tamamına 25-34 yaşlardaki sağlık çalışanlarının katılımı daha yüksek bulunmuştur (Tablo XI).

Sağlık çalışanlarının unvanları esas alınarak yapılan analizde zaman kaybını önleme $(p=0,012)$, tıbbi hizmetlerin daha kaliteli verilmesi $(p=0,037)$, çalışanların performansının ölçülmesi $(p=0,010)$, malzeme ihtiyaçlarının daha etkili planlanması $(p=0,024)$ ve malzeme sipariş ve takibinin daha etkili yapılması $(p=0,031)$ ifadelerinde istatistiksel açıdan anlamlı fark bulunmuştur. Zaman kaybını önleme, çalışanların performansının ölçülmesi ve malzeme sipariş ve takibinin daha etkili yapılması ifadelerindeki fark hemşire/ebeler ve sağlık teknisyeni/teknikerlerinden kaynaklanmaktadır. Her üç ifadeye de hemşire/ebelerin katılımı daha düşük olmasına karşılık, sağlık teknisyeni/ teknikerlerinin katılımı daha yüksek bulunmuştur. Hemşire/ebelerin katılımının daha düşük olduğu tıbbi hizmetlerin daha kaliteli verilmesi ifadesinde fark tıbbi sekreter ve 
hemşire/ebelerden kaynaklanmaktadır. Aynı şekilde malzeme ihtiyaçlarının daha etkili planlanması ifadesinde ise fark, hemşire/ebeler ile sağlık memurları ve sağlık teknisyeni/ teknikerlerinden kaynaklanmaktadır. Sonuç olarak, sağlık çalışanlarının unvanları esas alınarak yapılan analizde fark bulunan ifadelerin tamamına hemşire/ebelerin katılımı daha düşüktür. Bu sonuca göre hemşire/ebelerin HBS'nin faydalarına olan inançlarının daha düşük olduğu söylenebilir (Tablo XII).

Tablo XıI. Sağlık Çalışanlarının Hastane Bilgi Sistemi Kullanımının Faydaları İle İlgili Değerlendirmelerinin Unvanlarına Göre Dağılımı

\begin{tabular}{|c|c|c|c|c|c|c|c|}
\hline & & $\mathbf{n}$ & Ort. & S.S. & $\mathbf{F}$ & $\mathbf{p}$ & Post. Hoc. \\
\hline \multirow{5}{*}{$\begin{array}{l}\text { Zaman kaybını } \\
\text { önleme }\end{array}$} & Tıbbi sekreter ${ }^{1}$ & 192 & 3,99 & 1,386 & \multirow{5}{*}{3,264} & \multirow{5}{*}{0,012} & \multirow{5}{*}{$2-5 p=0,038$} \\
\hline & Hemşire/ebe ${ }^{2}$ & 162 & 3,68 & 1,382 & & & \\
\hline & Sağlık Memuru ${ }^{3}$ & 47 & 4,21 & 1,122 & & & \\
\hline & Memur ${ }^{4}$ & 103 & 4,03 & 1,061 & & & \\
\hline & Sağ. Teknis./Teknikeri ${ }^{5}$ & 40 & 4,33 & 1,163 & & & \\
\hline \multirow{5}{*}{$\begin{array}{l}\text { Tıbbi hizmetlerin } \\
\text { daha kaliteli } \\
\text { verilmesi }\end{array}$} & Tıbbi sekreter $^{1}$ & 192 & 4,06 & 1,344 & \multirow{5}{*}{2,566} & \multirow{5}{*}{0,037} & \multirow{5}{*}{$1-2 p=0,03 c$} \\
\hline & Hemşire/ebe ${ }^{2}$ & 162 & 3,76 & 1,418 & & & \\
\hline & Sağlık Memuru ${ }^{3}$ & 47 & 4,28 & 0,971 & & & \\
\hline & Memur $^{4}$ & 103 & 3,94 & 1,259 & & & \\
\hline & Sağ. Teknis./Teknikeri ${ }^{5}$ & 40 & 4,30 & 1,114 & & & \\
\hline \multirow{5}{*}{$\begin{array}{l}\text { Çalışanların } \\
\text { performansının } \\
\text { ölçülmesi }\end{array}$} & Tıbbi sekreter $^{1}$ & 192 & 3,66 & 1,550 & \multirow{5}{*}{3,354} & \multirow{5}{*}{0,010} & \multirow{5}{*}{$\begin{array}{c}2-5 \\
p=0,037\end{array}$} \\
\hline & Hemşire/ebe ${ }^{2}$ & 162 & 3,31 & 1,625 & & & \\
\hline & Sağlık Memuru ${ }^{3}$ & 47 & 3,96 & 1,250 & & & \\
\hline & Memur $^{4}$ & 103 & 3,75 & 1,398 & & & \\
\hline & Sağ. Teknis./Teknikeri ${ }^{5}$ & 40 & 4,08 & 1,403 & & & \\
\hline \multirow{5}{*}{$\begin{array}{l}\text { Malzeme } \\
\text { ihtiyaçlarının } \\
\text { daha etkili } \\
\text { planlanması }\end{array}$} & Tıbbi sekreter ${ }^{1}$ & 192 & 3,81 & 1,503 & \multirow{5}{*}{2,826} & \multirow{5}{*}{0,024} & \multirow{5}{*}{$\begin{array}{l}2-3 p=0,009 \\
2-5 p=0,010\end{array}$} \\
\hline & Hemşire/ebe ${ }^{2}$ & 162 & 3,54 & 1,569 & & & \\
\hline & Sağlık Memuru ${ }^{3}$ & 47 & 4,17 & 1,110 & & & \\
\hline & Memur ${ }^{4}$ & 103 & 3,83 & 1,368 & & & \\
\hline & Sağ. Teknis./Teknikeri ${ }^{5}$ & 40 & 4,20 & 1,381 & & & \\
\hline \multirow{5}{*}{$\begin{array}{l}\text { Malzeme sipariş } \\
\text { ve takibinin daha } \\
\text { etkili yapılması }\end{array}$} & Tıbbi sekreter ${ }^{1}$ & 192 & 3,84 & 1,504 & \multirow{5}{*}{2,687} & \multirow{5}{*}{0,031} & \multirow{5}{*}{$2-5 p=0,037$} \\
\hline & Hemşire/ebe ${ }^{2}$ & 162 & 3,57 & 1,548 & & & \\
\hline & Sağlık Memuru³ & 47 & 4,09 & 1,195 & & & \\
\hline & Memur $^{4}$ & 103 & 3,80 & 1,424 & & & \\
\hline & Sağ. Teknis./Teknikeri ${ }^{5}$ & 40 & 4,30 & 1,181 & & & \\
\hline
\end{tabular}


Sağlık çalışanlarının tıbbi ya da idari birimlerde görev yapmaları esas alınarak yapılan analizde maliyetleri azaltma ( $p=0,013)$, tıbbi hizmetlerin daha kaliteli verilmesi $(p=0,014)$, bilgilere daha kolay ulaşma $(p=0,025)$, malzeme ihtiyaçlarının daha etkili planlanması $(p=0,011)$, malzeme sipariş ve takibinin daha etkili yapılması $(p=0,037)$, poliklinik hastalarına randevu verme ve hasta atama $(p=0,010)$, kalite yönetimine destek olma $(p=0,002)$, laboratuvar testlerinin analizi $(p=0,001)$, tıbbi görüntülerin analizi $(p=0,000)$, ilaç ve diğer tıbbi cihaz ve sarf malzemelerinin takibi $(p=0,002)$ ve bilgisayar destekli tıbbi karar alma $(p=0,003)$ ifadelerinde istatistiksel açıdan anlamlı fark bulunmuştur. Fark bulunan ifadelerin tamamına tıbbi birimlerde görevli sağlık çalışanlarının katılımı daha yüksek bulunmuştur. Bu sonuca göre, tıbbi birimlerde görevli sağlık çalışanlarının HBS'nin yararına daha fazla inandığı söylenebilir (Tablo XIII).

Tablo XIII. Sağlık Çalışanlarının Hastane Bilgi Sistemi Kullanımının Faydaları İle İlgili Değerlendirmelerinin Çalıştıkları Birime Göre Dağılımı

\begin{tabular}{|c|c|c|c|c|c|c|}
\hline & & $\mathbf{n}$ & Ort. & S.S & $\mathbf{t}$ & $\mathbf{p}$ \\
\hline \multirow{2}{*}{ Maliyetleri azaltma } & İdari & 206 & 3,57 & 1,544 & \multirow{2}{*}{$-2,072$} & \multirow{2}{*}{0,013} \\
\hline & Tibbi & 338 & 3,84 & 1,388 & & \\
\hline \multirow{2}{*}{$\begin{array}{l}\text { Tıbbi hizmetlerin daha kaliteli } \\
\text { verilmesi }\end{array}$} & İdari & 206 & 3,82 & 1,418 & \multirow{2}{*}{$-2,218$} & \multirow{2}{*}{0,014} \\
\hline & Tibbi & 338 & 4,09 & 1,240 & & \\
\hline \multirow{2}{*}{ Bilgilere daha kolay ulaşma } & İdari & 206 & 4,02 & 1,363 & \multirow{2}{*}{$-2,234$} & \multirow{2}{*}{0,025} \\
\hline & Tibbi & 338 & 4,28 & 1,102 & & \\
\hline \multirow{2}{*}{$\begin{array}{l}\text { Malzeme ihtiyaçlarının daha etkili } \\
\text { planlanması }\end{array}$} & İdari & 206 & 3,66 & 1,563 & \multirow{2}{*}{$-1,656$} & \multirow{2}{*}{0,011} \\
\hline & Tibbi & 338 & 3,88 & 1,407 & & \\
\hline \multirow{2}{*}{$\begin{array}{l}\text { Malzeme sipariş ve takibinin daha } \\
\text { etkili yapılması }\end{array}$} & İdari & 206 & 3,70 & 1,545 & \multirow{2}{*}{$-1,291$} & \multirow{2}{*}{0,037} \\
\hline & Tibbi & 338 & 3,87 & 1,414 & & \\
\hline \multirow{2}{*}{$\begin{array}{l}\text { Poliklinik hastalarına randevu } \\
\text { verme ve hasta atama }\end{array}$} & İdari & 206 & 3,78 & 1,591 & \multirow{2}{*}{$-1,652$} & \multirow{2}{*}{0,010} \\
\hline & Tibbi & 338 & 4,01 & 1,441 & & \\
\hline \multirow{2}{*}{ Kalite yönetimine destek olma } & İdari & 206 & 3,67 & 1,613 & \multirow{2}{*}{$-2,172$} & \multirow{2}{*}{0,002} \\
\hline & Tıbbi & 338 & 3,97 & 1,412 & & \\
\hline \multirow{2}{*}{ Laboratuvar testlerinin analizi } & İdari & 206 & 3,55 & 1,672 & \multirow{2}{*}{$-2,477$} & \multirow{2}{*}{0,001} \\
\hline & Tıbbi & 338 & 3,90 & 1,457 & & \\
\hline \multirow{2}{*}{ Tıbbi görüntülerin analizi } & İdari & 206 & 3,52 & 1,713 & \multirow{2}{*}{$-2,634$} & \multirow{2}{*}{0,000} \\
\hline & Tibbi & 338 & 3,90 & 1,468 & & \\
\hline \multirow{2}{*}{$\begin{array}{l}\text { İlaç ve diğer tıbbi cihaz ve sarf } \\
\text { malzemelerinin takibi }\end{array}$} & İdari & 206 & 3,54 & 1,690 & \multirow{2}{*}{$-2,309$} & \multirow{2}{*}{0,002} \\
\hline & Tibbi & 338 & 3,87 & 1,504 & & \\
\hline \multirow{2}{*}{ Bilgisayar destekli tıbbi karar alma } & İdari & 206 & 3,36 & 1,780 & \multirow{2}{*}{$-2,190$} & \multirow{2}{*}{0,003} \\
\hline & Tibbi & 338 & 3,70 & 1,590 & & \\
\hline
\end{tabular}


Tablo XIV'de sağlık çalışanlarının çalışma şekillerine göre HBS'ni değerlendirmelerine ilişkin bulgular verilmiştir. Sağlık çalışanlarının çalışma şekilleri esas alınarak yapılan analizde zaman kaybını önleme $(p=0,001)$, maliyetleri azaltma $(p=0,002)$, tıbbi hizmetlerin daha kaliteli verilmesi $(p=0,008)$, çalışanların performansının ölçülmesi $(p=0,001)$, malzeme ihtiyaçlarının daha etkili planlanması $(p=0,001)$, malzeme sipariş ve

Tablo XIV. Sağlık Çalışanlarının Hastane Bilgi Sistemi Kullanımının Faydaları İle İlgili Değerlendirmelerinin Çalışma Şekline Göre Dağılımı

\begin{tabular}{|c|c|c|c|c|c|c|c|}
\hline & & $\mathbf{n}$ & Ort. & S.S. & $\mathbf{F}$ & $\mathbf{p}$ & Post Hoc. \\
\hline \multirow{3}{*}{ Zaman kaybını önleme } & Gündüz' & 372 & 4,07 & 1,227 & \multirow{3}{*}{7,149} & \multirow{3}{*}{0,001} & \multirow{3}{*}{$\begin{array}{c}1-3 \\
p=0,001\end{array}$} \\
\hline & Nöbet ${ }^{2}$ & 75 & 3,92 & 1,383 & & & \\
\hline & Vardiya $^{3}$ & 97 & 3,52 & 1,437 & & & \\
\hline \multirow{3}{*}{ Maliyetleri azaltma } & Gündüz ${ }^{1}$ & 372 & 3,82 & 1,437 & \multirow{3}{*}{6,096} & \multirow{3}{*}{0,002} & \multirow{3}{*}{$\begin{array}{c}1-3(p=0,003) 2-3 \\
(p=0,013)\end{array}$} \\
\hline & Nöbet $^{2}$ & 75 & 3,91 & 1,416 & & & \\
\hline & Vardiya $^{3}$ & 97 & 3,28 & 1,470 & & & \\
\hline \multirow{3}{*}{$\begin{array}{l}\text { Tıbbi hizmetlerin daha } \\
\text { kaliteli verilmesi }\end{array}$} & Gündüz'1 & 372 & 4,10 & 1,234 & \multirow{3}{*}{4,869} & \multirow{3}{*}{0,008} & \multirow{3}{*}{$\begin{array}{c}1-3 \\
p=0,008\end{array}$} \\
\hline & Nöbet ${ }^{2}$ & 75 & 3,87 & 1,501 & & & \\
\hline & Vardiya $^{3}$ & 97 & 3,65 & 1,415 & & & \\
\hline \multirow{3}{*}{$\begin{array}{l}\text { Çalışanların } \\
\text { performansının } \\
\text { ölçülmesi }\end{array}$} & Gündüz ${ }^{1}$ & 372 & 3,80 & 1,442 & \multirow{3}{*}{7,483} & \multirow{3}{*}{0,001} & \multirow{3}{*}{$\begin{array}{l}1-2(p=0,048) \\
1-3(p=0,002)\end{array}$} \\
\hline & Nöbet $^{2}$ & 75 & 3,35 & 1,664 & & & \\
\hline & Vardiya $^{3}$ & 97 & 3,21 & 1,620 & & & \\
\hline \multirow{3}{*}{$\begin{array}{l}\text { Malzeme ihtiyaçlarının } \\
\text { daha etkili planlanması }\end{array}$} & Gündüz'1 & 372 & 3,94 & 1,353 & \multirow{3}{*}{7,042} & \multirow{3}{*}{0,001} & \multirow{3}{*}{$\begin{array}{c}1-3 \\
p=0,000\end{array}$} \\
\hline & Nöbet $^{2}$ & 75 & 3,64 & 1,548 & & & \\
\hline & Vardiya $^{3}$ & 97 & 3,34 & 1,731 & & & \\
\hline \multirow{3}{*}{$\begin{array}{l}\text { Malzeme sipariş ve } \\
\text { takibinin daha etkili } \\
\text { yapılması }\end{array}$} & Gündüz' & 372 & 3,93 & 1,354 & \multirow{3}{*}{4,345} & \multirow{3}{*}{0,013} & \multirow{3}{*}{$\begin{array}{c}1-3 \\
p=0,034\end{array}$} \\
\hline & Nöbet $^{2}$ & 75 & 3,56 & 1,646 & & & \\
\hline & Vardiya $^{3}$ & 97 & 3,52 & 1,672 & & & \\
\hline \multirow{3}{*}{$\begin{array}{l}\text { Poliklinik hastalarına } \\
\text { randevu verme ve hasta } \\
\text { atama }\end{array}$} & Gündüz' & 372 & 4,03 & 1,428 & \multirow{3}{*}{3,576} & \multirow{3}{*}{0,029} & \multirow{3}{*}{$\begin{array}{c}1-2 \\
p=0,036\end{array}$} \\
\hline & Nöbet $^{2}$ & 75 & 3,56 & 1,869 & & & \\
\hline & Vardiya $^{3}$ & 97 & 3,78 & 1,423 & & & \\
\hline \multirow{3}{*}{ Tıbbi görüntülerin analizi } & Gündüz ${ }^{1}$ & 372 & 3,88 & 1,496 & \multirow{3}{*}{4,394} & & \\
\hline & Nöbet $^{2}$ & 75 & 3,64 & 1,721 & & 0,013 & $\begin{array}{c}1-3 \\
n=0012\end{array}$ \\
\hline & Vardiya $^{3}$ & 97 & 3,37 & 1,691 & & & \\
\hline & Gündüz ${ }^{1}$ & 372 & 3,67 & 1,645 & & & \\
\hline $\begin{array}{l}\text { Istem ve tedavi } \\
\text { sonuclarının qirisi }\end{array}$ & Nöbet $^{2}$ & 75 & 3,11 & 1,907 & 3,617 & 0,028 & $\begin{array}{c}1-2 \\
p=0.020\end{array}$ \\
\hline & Vardiya $^{3}$ & 97 & 3,60 & 1,518 & & & \\
\hline & Gündüz ${ }^{1}$ & 372 & 3,78 & 1,613 & & & \\
\hline Bordro hazırlama ve & Nöbet $^{2}$ & 75 & 3,39 & 1,902 & 3,606 & 0,028 & $\begin{array}{c}1-3 \\
0=0.025\end{array}$ \\
\hline & Vardiya $^{3}$ & 97 & 3,35 & 1,820 & & & \\
\hline
\end{tabular}


takibinin daha etkili yapılması $(p=0,013)$, poliklinik hastalarına randevu verme ve hasta atama ( $p=0,029)$, tıbbi görüntülerin analizi $(p=0,013)$, istem ve tedavi sonuçlarının girişi $(p=0,028)$ ve bordro hazırlama ve hesap çıkarma $(p=0,028)$ ifadelerinde istatistiksel açıdan anlamlı fark bulunmuştur. Zaman kaybını önleme, tıbbi hizmetlerin daha kaliteli verilmesi, malzeme ihtiyaçlarının daha etkili planlanması, malzeme sipariş ve takibinin daha etkili yapılması ve bordro hazırlama ve hesap çıkarma ifadelerinde fark gündüz mesai saatleri içerisinde çalışan katılımcılar ile vardiya usulü çalışan katılımcılardan kaynaklanmaktadır. Ifadelerin tamamına vardiya usulü çalışanların katılımı daha düşük bulunmuştur. Poliklinik hastalarına randevu verme ve hasta atama ve tıbbi görüntülerin analizi ifadelerinde fark gündüz mesai saatlerinde çalışan katılımcılar ile nöbet usulü çalışanlardan kaynaklanmaktadır. Her iki ifadeye de nöbet usulü çalışanların katııımı daha düşüktür. Maliyetleri azaltma ifadesinde fark vardiya usulü çalışan katılımcılar ile gündüz ve nöbet usulü çalışan katııımılardan kaynaklanmaktadır. Ifadeye vardiya usulü çalışanların katılımı daha düşük bulunmuştur. Çalışanların performansının ölçülmesi ifadelerinde ise fark gündüz çalışan katılımcılar ile nöbet ve vardiya usulü çalışan katılımcılardan kaynaklanmaktadır. Ifadeye nöbet ve vardiya usulü çalışanların katılımı daha düşüktür. Bu sonuca göre gündüz mesai saatleri içinde çalışanların HBS'nin kullanımının faydalarına daha fazla inandıkları söylenebilir. Bu sonuçta mesai saatleri dışında çalışan personelin bilgi sistemleri uygulamalarına çok fazla katılmamaları ya da bilgi sisteminden elde edilen bulguları çok fazla kullanmamaları etkili olabilir.

Tablo XV'de görüldüğü gibi, HBS konusunda eğitim alma durumları esas alınarak yapılan analizde ölçeği oluşturan ifadelerin tamamında istatistiksel açıdan anlamlı fark bulunmuştur $(p<0,05)$. Ifadelerin tamamında HBS konusunda eğitim alanların katılımı daha yüksek bulunmuştur. Bu sonuçtan hareketle bu alanda eğitim alan sağlık çalışanları sistemi daha iyi bildikleri için faydalarını da daha iyi değerlendirdikleri söylenebilir.

Tablo XVI'da görüldüğü gibi, hastanelerin mülkiyeti esas alınarak yapılan analizde bilgisayar destekli tıbbi karar alma, istem ve tedavi sonuçlarının girişi, hasta bakımının planlanması, envanter kontrolü ve bordro hazırlama ve hesap çıkarma ifadelerinde istatistiksel açıdan anlamlı farkbulunmuştur $(p<0,05)$. Farkbulunan ifadelerin tamamında kamu hastanelerinin özel hastanelerden daha üstün olduğu görülmektedir. Bu sonuçta kamu hastanelerinde son yıllarda hızla gelişen bilgi teknolojilerinin kullanımı ve Sağlık Bakanlığı hastanelerinin bir ağ üzerinde birbirlerinin bilgilerine ulaşabilmelerinin sağlanmasının etkili olduğu düşünülmektedir. 
Tablo XV. Sağlık Çalışanlarının Hastane Bilgi Sistemi Kullanımının Faydaları İle İlgili Değerlendirmelerinin Hastane Bilgi Sistemleri Konusunda Herhangi Bir Eğitim Alma Durumlarına Göre Dağılımı

\begin{tabular}{|c|c|c|c|c|c|c|}
\hline & & $\mathbf{n}$ & Ort. & S.S & $\mathbf{t}$ & $\mathbf{p}$ \\
\hline \multirow{2}{*}{ Zaman kaybını önleme } & Alan & 445 & 3,98 & 1,259 & \multirow{2}{*}{0,929} & \multirow{2}{*}{0,011} \\
\hline & Almayan & 99 & 3,83 & 1,485 & & \\
\hline \multirow{2}{*}{ Maliyetleri azaltma } & Alan & 445 & 3,83 & 1,357 & \multirow{2}{*}{2,806} & \multirow{2}{*}{0,000} \\
\hline & Almayan & 99 & 3,30 & 1,770 & & \\
\hline \multirow{2}{*}{ Tıbbi hizmetlerin daha kaliteli verilmesi } & Alan & 445 & 4,03 & 1,272 & \multirow{2}{*}{1,654} & \multirow{2}{*}{0,012} \\
\hline & Almayan & 99 & 3,77 & 1,483 & & \\
\hline \multirow{2}{*}{ Bilgilere daha kolay ulaşma } & Alan & 445 & 4,25 & 1,130 & \multirow{2}{*}{2,386} & \multirow{2}{*}{0,004} \\
\hline & Almayan & 99 & 3,87 & 1,496 & & \\
\hline \multirow{2}{*}{$\begin{array}{l}\text { Çalışanlar arasında iletişimi } \\
\text { kolaylaştırma }\end{array}$} & Alan & 445 & 3,98 & 1,290 & \multirow{2}{*}{1,798} & \multirow{2}{*}{0,000} \\
\hline & Almayan & 99 & 3,67 & 1,623 & & \\
\hline \multirow{2}{*}{ Çalışanların performansının ölçülmesi } & Alan & 445 & 3,71 & 1,466 & \multirow{2}{*}{2,200} & \multirow{2}{*}{0,005} \\
\hline & Almayan & 99 & 3,29 & 1,734 & & \\
\hline \multirow{2}{*}{$\begin{array}{l}\text { Malzeme ihtiyaçlarının daha etkili } \\
\text { planlanması }\end{array}$} & Alan & 445 & 3,86 & 1,408 & \multirow{2}{*}{2,124} & \multirow{2}{*}{0,001} \\
\hline & Almayan & 99 & 3,47 & 1,692 & & \\
\hline \multirow{2}{*}{$\begin{array}{l}\text { Malzeme sipariş ve takibinin daha etkili } \\
\text { yapılması }\end{array}$} & Alan & 445 & 3,87 & 1,399 & \multirow{2}{*}{1,851} & \multirow{2}{*}{0,000} \\
\hline & Almayan & 99 & 3,53 & 1,716 & & \\
\hline \multirow{2}{*}{$\begin{array}{l}\text { Ameliyathane ve tanı ünitelerini daha } \\
\text { etkili planlama }\end{array}$} & Alan & 445 & 3,69 & 1,564 & \multirow{2}{*}{2,757} & 0,000 \\
\hline & Almayan & 99 & 3,13 & 1,893 & & o,000 \\
\hline Poliklinik hastalarına randevu verme ve & Alan & 445 & 4,05 & 1,380 & 3495 & 0000 \\
\hline hasta atama & Almayan & 99 & 3,35 & 1,864 & 3,495 & 0,000 \\
\hline Kalite vönetimine dectek olma & Alan & 445 & 3,92 & 1,439 & 1798 & 0001 \\
\hline 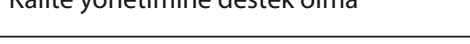 & Almayan & 99 & 3,59 & 1,714 & 1,190 & 0,001 \\
\hline I aboratuvar toctlorinin an alizi & Alan & 445 & 3,87 & 1,468 & 2706 & 00000 \\
\hline Laboratuvar testiermin analizl & Almayan & 99 & 3,32 & 1,817 & 2,190 & 0,000 \\
\hline Tıbbi görüntülerin analizi & Alan & 445 & 3,87 & 1,487 & 3,126 & 0,000 \\
\hline IIDDO goruntulerin dnallz & Almayan & 99 & 3,25 & 1,842 & & \\
\hline İlaç ve diğer tıbbi cihaz ve sarf & Alan & 445 & 3,85 & 1,503 & 3.047 & 0,000 \\
\hline malzemelerinin takibi & Almayan & 99 & 3,25 & 1,831 & & \\
\hline Bilaicayar desteklitubhi karar alma & Alan & 445 & 3,67 & 1,616 & 2673 & 0008 \\
\hline 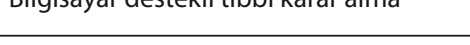 & Almayan & 99 & 3,13 & 1,844 & $2,0 / 5$ & , \\
\hline İstem ve tedavi sonuclarının airisj & Alan & 445 & 3,67 & 1,605 & 2444 & 0.001 \\
\hline & Almayan & 99 & 3,17 & 1,890 & & \\
\hline Hasta hakımının nlanlanması & Alan & 445 & 3,51 & 1,613 & 1.444 & 0.012 \\
\hline Hasta Dakımının planıanması & Almayan & 99 & 3,22 & 1,849 & 1,444 & 0,012 \\
\hline Envanter kontrolü & Alan & 445 & 3,49 & 1,718 & 1824 & 0.013 \\
\hline & Almayan & 99 & 3,11 & 1,927 & & \\
\hline Bordro hazırlama ve hesan a & Alan & 445 & 3,73 & 1,639 & 1985 & 0,000 \\
\hline Do & Almayan & 99 & 3,31 & 1,931 & (1, & 0,000 \\
\hline
\end{tabular}


Tablo XVI. Sağlık Çalışanlarının Hastane Bilgi Sistemi Kullanımının Faydaları İle İlgili Değerlendirmelerinin Hastanelerin Mülkiyetine Göre Dağılımı

\begin{tabular}{|c|c|c|c|c|c|c|}
\hline Mülkiyet & & $\mathbf{n}$ & Ort. & S.S. & $\mathbf{t}$ & $\mathbf{p}$ \\
\hline \multirow{2}{*}{ Bilgisayar destekli tıbbi karar alma } & Kamu & 421 & 3,62 & 1,649 & \multirow{2}{*}{1,197} & \multirow{2}{*}{$0,04 C$} \\
\hline & Özel & 123 & 3,41 & 1,741 & & \\
\hline \multirow{2}{*}{ İstem ve tedavi sonuçlarının girişi } & Kamu & 421 & 3,64 & 1,622 & \multirow{2}{*}{1,353} & \multirow{2}{*}{0,003} \\
\hline & Özel & 123 & 3,39 & 1,818 & & \\
\hline \multirow{2}{*}{ Hasta bakımının planlanması } & Kamu & 421 & 3,55 & 1,620 & \multirow{2}{*}{2,280} & \multirow{2}{*}{0,012} \\
\hline & Özel & 123 & 3,15 & 1,763 & & \\
\hline \multirow{2}{*}{ Envanter kontrolü } & Kamu & 421 & 3,52 & 1,707 & \multirow{2}{*}{2,150} & \multirow{2}{*}{0,001} \\
\hline & Özel & 123 & 3,11 & 1,915 & & \\
\hline \multirow{2}{*}{ Bordro hazırlama ve hesap çıkarma } & Kamu & 421 & 3,77 & 1,607 & \multirow{2}{*}{2,696} & \multirow{2}{*}{0,000} \\
\hline & Özel & 123 & 3,25 & 1,944 & & \\
\hline
\end{tabular}

\section{Sonuç ve Öneriler}

Bilgi teknolojilerinin öneminin gittikçe arttığı sağlık hizmetlerinde, hizmetlerin etkili, verimli ve kaliteli sunulması açısından sağlık çalışanlarının bilgi teknolojilerini kullanımı önem arz etmektedir. Araştırma sonuçlarına göre sağlık çalışanlarının Office programları, işletim sistemleri ve bilgisayar donanımı konularında daha yetkin görünmelerine karşılık, veri tabanı, network ve ses kayıt dinleme cihazları konusunda daha sınırlı bilgiye sahip oldukları görülmektedir.

Sağlık çalışanlarının çoğunluğu kendilerini HBS'ni kullanma konusunda kendilerini yeterli $(\% 60,3)$ ve kısmen yeterli $(\% 23,3)$ görmektedirler. Özellikle çalışanların bilgi sistemi konusunda kendini yeterli görmesi ile bu alanda eğitim alması arasında anlamlı bir ilişki bulunmaktadır. Dolayısıyla çalışanların büyük bir kısmının bu konuda eğitim almış olması bu sonucun çıkmasında etkili olmuştur. Bu nedenle değişen ve gelişen teknolojiye paralel olarak çalışanların gelişimini de sağlamak için sürekli eğitim yöntemlerinden yararlanılarak eğitim verilmesi, hizmetin sürekliliği ve verimliliği açısından önemli görülmektedir.

Sağlık çalışanlarının büyük çoğunluğunun $(\% 64,3)$ HBS konusunda hizmet içi eğitim aldıkları belirlenmiştir. HBS konusunda örgün öğretim aşamasında eğitim alanların oranı ise sadece \%12,8'dir. Dolayısıyla sektör ile eğitim birimleri arasındaki iletişimin geliştirilmesi ve sağlık alanında eğitim veren okulların müfredatlarına HBS konusunda derslerin eklenmesi veya mevcut derslerin güncellenmesinin uygun olacağı düşünülmektedir. 
Günümüzde teknolojinin yoğun olarak kullanıldığı hastaneler aynı zamanda emek yoğun işletmelerdir. Dolayısıyla insan sağlığını doğrudan ilgilendiren ve hataların telafisi çok zor olan hizmetleri sunan hastanelerde bilgi teknolojilerinin faydalarının önemi aşikârdır. Ancak araştırma sonucunda sağlık çalışanlarının yaklaşık olarak \%17'si bilgi teknolojilerinin çalıştıkları birim için önemli olmadığı görüşüne sahiptir. Bu sonucun çalışanların bilgi teknolojilerini yeteri kadar bilmedikleri ve kullanamadıklarından kaynaklandığı düşünülmektedir. Bu nedenle hastane yönetimlerinin bu eksikliği giderici eğitim programları planlamaları önerilmektedir.

Sağlık çalışanları HBS'nin en çok fayda sağladığı alanları, bilgilere daha kolay ulaşma $(\% 85,2)$, poliklinik hastalarına randevu verme ve hasta atama $(\% 79,4)$, tıbbi hizmetlerin daha kaliteli verilmesi $(\% 79,2)$, çalışanlar arasında iletişimi kolaylaştırma $(\% 76,9)$ ve zaman kaybının önlenmesi $(\% 76,1)$ olarak ifade etmişlerdir. HBS'nin faydaları konusunda olumsuz düşünen çalışanların, daha çok bu konuda herhangi bir eğitim almayanlardan oluştuğu görülmektedir. Çalışanların özellikleri dikkate alındığında yapılan değerlendirme sonucunda ise, daha çok hemşireler/ebeler, idari birimlerde çalışanlar ve vardiyalı çalışanlar HBS'nin faydaları konusunda daha olumsuz bir görünüm içerisindedirler. Bu sonuçta HBS kullanımının da etkili olduğu düşünülmektedir. HBS konusunda olumsuz düşünenler sistemi daha az kullanan gruplardan oluşmaktadır. Dolayısı ile bu kesime yönelik eğitim hizmetleri verilerek ve zaman zaman sistemi daha yoğun kullanabilecekleri alanlarda görevlendirmek suretiyle HBS konusundaki düşüncelerinin değiştirilmesi sağlanabilir.

Sonuçta genel olarak sağlık çalışanları bilgi sistemlerinin önemine inanmakta ve özellikle hizmet içi eğitim şeklinde bilgi sistemleri konusunda eğitim almaktadırlar ve bilgi teknolojileri kullanımında kendilerini yeterli görmektedirler. Bununla birlikte son yıllarda sağlık hizmetleri sunumunda bilgi teknolojileri kullanımının artan önemine paralel olarak sağlık çalışanlarının bilgi teknolojileri kullanımı yeteneğinin geliştirilmesi de büyük önem arz etmektedir. Özellikle HBS'nin bilgi teknolojileri temelli olarak gelişmesi bu uygulamayı zorunlu kılmaktadır.

\section{Kaynakça}

Ak, B. (2009). Türkiye'de sağlık bilişimi, bir kişisel değerlendirme ve uluslararası bir başarı öyküsü: CorTTex. Akademik Bilişim'09 - XI. Akademik Bilişim Konferansı Bildirileri, 11-13 Şubat 2009 Harran Üniversitesi, Şanlıurfa, 333-341.

Aktaş, A., Zayim, N. ve Saka, O. (2007). Sağlıkta insan-bilgisayar etkileşimi. Akademik Bilişim'07 - IX. Akademik Bilişim Konferansı Bildirileri, 31 Ocak - 2 Şubat, Kütahya: Dumlupınar Üniversitesi, 425-430.

Altunışık R., Coşkun R., Bayraktaroğlu S. ve Yıldırım E. (2005). Sosyal bilimlerde araştırma yöntemleri SPSS uygulamalı. Sakarya: Sakarya Kitabevi.

Austin, C.J. ve Wager, K. A. (1998). Health information systems. M. J. Duncan, P. M. Ginter ve L. E. Swayne (Eds.), In Handbook of health care management (ss.227-253). Blackwell Business 
Austin, C. J., Trimm, J. M. ve Sobczak, P. M. (1995). Information systems and strategic management. Health Care Management Review, 20(3), 26-33.

Avison, D. ve Elliot S. (2006). Scoping the discipline of information systems. John Leslie King and Kalle Lyytinen (Eds.), In Information systems the state of the field (ss. 1-18), West Sussex: John Wiley \& Sons Ltd.

Bal, H. (2001). Bilimsel araştırma yöntem ve teknikleri, Isparta: SDÜ yayın no:20, Süleyman Demirel Üniversitesi Basımevi.

Drucker, P. F. (1995). Değişim çağının yönetimi (Sayı: 4) (Z. Dicleli, Çev.). İstanbul: Henkel.

Esatoğlu, A. E. ve Köksal A. (2002). Hastanelerde bilgisayar teknolojisi kullanımı. Ankara Üniversitesi Tıp Fakültesi Mecmuası, 55(1), 29-40.

Güredin, E. (1987). Denetim. İstanbul: Avcıol Matbaası.

Harris M. F., Priddin D., Ruscoe W., Infante F. A. ve O'toole B. I. (2002). Quality of care provided by general practitioners using or not using division-based diabetes registers. Medical Journal of Australia, 177(5), 250-252.

Haux, R. (2006). Health information systems; past, present, future. International Journal of Medical Informatics, 75, 268-281.

Haux, R., Winter A., Ammenwerth, E. ve Brigl, B. (2004). Strategic information management in hospitals: an introduction to hospital information systems. New York: Springer.

Hevner, A. R., Salvatore T. M., Jinsoo P. ve Sudha R. (2006). Design science in information systems research. John Leslie King And Kalle Lyytinen (Eds.). In, Information Systems The State of the Field (ss. 191-232). West Sussex: John Wiley \& Sons Ltd.

Kök, S. B. (2006). Bilişim teknolojilerini yönetsel ve örgütsel etkileri. Ticaret ve Turizm Eğitim Fakültesi Dergisi, 2, 123-140.

Köksal, A. ve Esatoğlu A. E. (2005). Ankara ilindeki üniversite ve özel hastanelerde kullanılan elektronik hastane bilgi sisteminin analizi. Ankara Üniversitesi Dikimevi Sağlık Hizmetleri Meslek Yüksekokulu Dergisi, 7(1), 53-65.

Kuperman G. J., Spurr, C., Flammini S., Bates D. ve Glaser J. (2000). A clinical information systems strategy for a large integrated delivery network. Proc AMIA Symp., 438-442.

Onat, A. (2010). Özel hastanelerde bilgi yönetimi: Bir araştırma. Yayınlanmamış yüksek lisans tezi, İstanbul üniversitesi, İstanbul.

Öğüt, A. (2001). Bilgi çağında yönetim. İstanbul: Nobel Basım Yayım Dağıtım.

Özata, M. ve Aslan, Ş. (2004). Klinik karar destek sistemleri ve örnek uygulamalar. Kocatepe Tıp Dergisi, 5, 11-18.

Rodoplu, D. (2007-2008). Bilgi teknolojileri uygulamalarına karşı çalışan direnci; hastane bilgi sistemi üzerinde bir uygulama. Review of Social, Economic \& Business Studies, (9) 10, 409-438.

Safran, C. (2003). The collaborative edge: patient empowerment for vulnerable populations. International Journal of Medical Informatics, 69(2-3), 185-190.

Sağlık Bakanlığı, (2008). Türkiye sağlıkta dönüşüm programı ilerleme raporu. Ankara: TC Sağlık Bakanlığı Yayın No:749. 
Tan, J. K. H. ve Hanna, J. (1994). Integrating health care with information technology: knitting patient information through networking. Health Care Management Review, 19(2), 5-92.

Tengilimoğlu, D., Işık, O. ve Akbolat M. (2009). Sağlık İşletmeleri Yönetimi. Ankara: Nobel Yayın Dağıtım. eser adi bas harflei kucuk.

Wan T. T. H., Lin, Blossom Yen-Ju ve Ma, A., (2002). Integration mechanisms and hospital efficiency in integrated health care delivery systems. Journal of Medical Systems, 26(2),127-143.

Wang, S. J., Middleton B., Prosser L. A., Bardon C. G., Spurr C. D., Carchidi P. J. ve diğerleri. (2003). A cost-benefit analysis of electronic medical records in primary care. The American Journal of Medicine, 114 (5), 397-403.

Yılmaz, A. ve Aloğlu E. (2002). Hastane Bilgi Sistemleri. 5. Ulusal sağılk kuruluşları ve hastane yönetimi sempozyum kitabı. Eskişehir: 16-19 Ekim, 331-339. 